\title{
ANALISIS KEBIJAKAN PENDIRIAN SEKOLAH DASAR DI KABUPATEN BATU BARA
}

\section{Regina Sipayung, Din Oloan Sihotang, Johannes Sohirimon Lumban Batu}

Surel: sipayungregina1@gmail.com

\begin{abstract}
This study uses a descriptive methodology with interview data collection techniques, observation and documentation studies. The results showed that of the 17 schools that were established and categorized since 2018 it was found that $37 \%$ of the schools did not meet the study group requirements because there were less than 20 students. Then, judging from the communication process, the socialization of the requirements for the establishment of schools has not been carried out properly, information regarding the determination of school conditions is only conveyed to the school establishment committee. The readiness of resources has not been met and the disposition process still needs attention. The bureaucratic structure factor is still not clear, the standard operational procedures of the Batu Bara District Education Office have been guided by Kepmendiknas No. 060/U/2002. Based on the conclusion of this study, it was found that the Education Office of Batu Bara Regency had implemented policies in accordance with the Ministry of National Education. Number 060/U/2002, but needs to do some repairs.
\end{abstract}

Keywords: Policy, School Establishment, Edwards

\begin{abstract}
ABSTRAK
Penelitian ini menggunakan metodologi deskriptif dengan teknik pengumpulan data wawancara, observasi dan studi dokumentasi. Hasil penelitian menunjukkan bahwa dari 17 sekolah yang didirikan dan dikategorikan sejak tahun 2018 ditemukan 37\% sekolah belum memenuhi persyaratan kelompok belajar karena siswanya kurang dari 20 orang. Kemudian dilihat dari proses komunikasi sosialisasi persyaratan pendirian sekolah belum terlaksana dengan baik, informasi penetapan kondisi sekolah hanya disampaikan kepada panitia pendirian sekolah saja. Kesiapan sumber daya belum terpenuhi dan proses disposisi masih perlu diperhatikan. Faktor struktur birokrasi masih belum jelas, prosedur operasional standar Dinas Pendidikan Kabupaten Batu Bara telah berpedoman pada Kepmendiknas Nomor. 060/U/2002. Berdasarkan kesimpulan penelitian ini diperoleh bahwa Dinas Pendidikan Kabupaten Batu Bara telah melaksanakan implementasi kebijakan sesuai dengan Kepmendiknas. Nomor 060/U/2002, namun perlu melalukan beberapa perbaikan.
\end{abstract}

Kata Kunci: Kebijakan, Pendirian Sekolah, Edwards

\section{PENDAHULUAN}

Pemberlakuan Undang-

Undang Nomor 32 pada Tahun 2004 mengenai Pemerintah Daerah melimpahkan kewenangan pengelolaan pendidikan dan pengembangan pendidikan kepada
Pemerintah Kabupaten / Kota. Hal ini berimplikasi pada banyaknya sekolah yang didirikan di Kabupaten Batu Bara. Sesuai dengan Keputusan Menteri Pendidikan Nasional (Kemendiknas) No. 060/U/2002 tentang Pedoman Pendirian Sekolah, 
pembentukan satuan pendidikan dasar dan menengah harus memenuhi ketentuan sebagaimana diatur dalam Bab II mengenai Persyaratan Pembentukan Sekolah pada Pasal 4 yang meliputi sebagai berikut yaitu: (a) Hasil studi kelayakan; (b) Rencana Induk Pengembangan Sekolah (RIPS); (c) sumber peserta didik; (d) Tenaga pendidikan; (e) Tenaga nonpendidikan; (f) Kurikulum / program kegiatan pembelajaran; (g) Sumber pembiayaan; (h) Sarana dan Prasarana dan (i) pengelola sekolah (Bakti Asmara, 2017).

Pelimpahan kewenangan pendirian sekolah ke wilayah ini menjadi dasar hukum bagi kepala daerah (Mayya, 2019) untuk mendirikan sekolah baru khususnya di Kabupaten Batu Bara pada tahun 2014 untuk mendirikan dan meresmikan 17 sekolah tersebut, berdasarkan SK Kepala Dinas Pendidikan Kabupaten Batu Bara Nomor: 421/1656/2014 tanggal 3 Juli 2014. Kemudian pada tahun 2016 Pemerintah Kabupaten Batu Bara kembali mendirikan dan meresmikan 7 sekolah baru berstatus sekolah negeri. Kebijakan pendirian sekolah baru di Kabupaten Batu Bara semestinya mampu mengatasi permasalahan umum yang ada, yaitu kurangnya sarana dan prasarana yang cukup memadai, siswa yang kurang, tenaga pendidik dan kurangnya tenaga kependidikan di sekolah.

Menurut Robert Eyestone dalam Winarno (2012: 20) “mengatakan bahwa 'secara luas' kebijakan publik dapat diartikan sebagai hubungan suatu unit pemerintah dengan lingkungan". Selanjutnya berkaitan dengan konteks pencapaian tujuan suatu bangsa dan penyelesaian masalah masyarakat. Pernyataan mengenai kebijakan yang berkaitan dengan pemerintah juga diutarakan oleh George C. Edwards III (2003) dan Baginda et al (2020) mengedepankan pengertian kebijakan yang pemerintah nyatakan dan lakukan atau tidak lakukan. Kebijakan tersebut dapat menjadi sasaran program pemerintah. Keputusan dalam kebijakan tersebut dengan jelas terwujud dalam peraturan perundangundangan atau pidato pejabat tinggi pemerintah serta program dan tindakan pemerintah.

Amtu (2011), Oloan dkk (2020) mengemukakan bahwa kebijakan pendidikan adalah kebijakan publik di dalam bidang pendidikan. Kebijakan pendidikan adalah kebijakan yang ditujukan untuk mewujudkan pembangunan untuk negara-bangsa di bidang pendidikan, sebagai tujuan pembangunan negara dan bangsa secara keseluruhan. Kebijakan pendidikan mencakup seluruh sistem pendidikan mulai dari kegiatan Kementerian Pendidikan Nasional, Pemerintah Provinsi, Pemerintah Kabupaten/Kota dan perangkat legislatif pendamping, serta satuan pendidikan yang memerlukan kebijakan dukungan multilevel. Kebijakan tersebut mencakup semua bidang penyelenggaraan pendidikan pada semua tingkatan pengambil keputusan baik dari pusat maupun dari daerah. 
Berdasarkan pendapat para ahli di atas dapat disimpulkan bahwa kebijakan pendidikan adalah berbagai keputusan yang diambil sebagai pedoman dalam mengatur dan menyelenggarakan semua proses penyelenggaraan di bidang pendidikan berdasarkan peraturan perundangundangan sehingga dapat meningkatkan mutu pendidikan secara keseluruhan.

\section{METODE PENELITIAN}

Penelitian ini dilaksanakan selama 6 bulan di Dinas Pendidikan Kabupaten Batu Bara, dengan menggunakan metode deskriptif dengan tujuan berupa rumusan rekomendasi yang dapat disampaikan kepada pengambil kebijakan. Dalam penelitian ini subjek adalah informan yang mengetahui tentang suatu kebijakan sebagaimana dimaksud. Teknik pengumpulan data dalam penelitian ini menggunakan wawancara, observasi dan studi dokumentasi. Analisis data menggunakan teori implementasi kebijakan George C Edwards III dengan melihat faktor komunikasi, sumber daya, disposisi dan faktor struktur birokrasi.

\section{HASIL PENELITIAN DAN PEMBAHASAN}

Berdasarkan data yang diperoleh dari penelitian ini, proses pelaksanaan kebijakan pembentukan satuan pendidikan dasar dan menengah di Kabupaten Batu Bara belum berhasil mencapai tujuan. Hal ini terlihat dari banyaknya sekolah baru yang didirikan namun masih minim siswa, minimnya tenaga pengajar, belum adanya pemerataan guru dan juga minimnya fasilitas penunjang proses belajar mengajar. Upaya pembangunan sekolah, pemenuhan tenaga pendidik dan tenaga kependidikan serta sarana dan prasarana di sekolah yang dibangun pada tahun 2017 dan 2019 belum terlihat keseriusan pemenuhan yang dilakukan Pemerintah Kabupaten Batu Bara.

Hasil wawancara narasumber yang berkompeten di Dinas Pendidikan didasarkan pada faktorfaktor yang dapat digunakan untuk penjelasan implementasi kebijakan melalui penggunaan teori implementasi George C. Edwards III: Komunikasi, Sumber Daya, Disposisi dan Birokrasi Struktur.

\section{Pembahasan}

- Komunikasi

Faktor pertama yang berpengaruh terhadap pelaksanaan kebijakan pembentukan satuan di pendidikan dasar dan menengah adalah sosialisasi (Sipayung, 2018). Faktor sosialisasi memiliki tiga dimensi yaitu transmisi, kejelasan dan konsistensi. Hasil penelitian menunjukkan bahwa sosialisasi belum terlaksana dengan baik tetapi penyampaian informasinya secara global kepada panitia pembangunan sekolah yang datang ke kantor. Kejelasan informasi tentang pembentukan satuan pendidikan belum sepenuhnya dipahami oleh setiap pengambil kebijakan di Dinas 
Pendidikan Batu Bara saat ini. Implementasi isi Kemendiknas seperti persyaratan pendirian sekolah, langkah-langkah sebelum pendirian sekolah baru belum dipahami dengan baik.

- Sumber daya

Sumber daya adalah kewenangan untuk menjamin atau meyakini bahwa kebijakan yang diterapkan sesuai dengan aturan yang ada (Hasibuan et al, 2019). Kepala pembinaan sekolah dasar dan sekolah menengah pertama bertanggung jawab untuk membentuk tim verifikasi. Pekerjaan tim verifikasi ini menentukan apakah sekolah baru layak didirikan atau tidak. Lebih lanjut mengenai sarana, dalam hal ini sarana dan prasarana pembangunan sekolah baru menurut peneliti belum mencukupi, seperti ruang laboratorium dan peralatan yang belum ada. Proses belajar mengajar masih akan terganggu karena minimnya fasilitas ini. Berdasarkan wawancara staf, informasi, kewenangan dan fasilitas pelaksana, kebijakan pembentukan satuan pendidikan dasar dan menengah di atas Dinas Pendidikan Kabupaten Batu Bara belum sepenuhnya mempertimbangkan faktor sumber daya dalam pelaksanaan kebijakan tersebut.

\section{- Disposisi}

Pelaksanaan kebijakan di Dinas Pendidikan Batu Bara perlu peningkatan, karena pengangkatan birokrasi dalam hal ini staf dalam tim verifikasi kebijakan pembentukan satuan pendidikan belum ditetapkan dan dikukuhkan dalam Surat Keputusan (SK). Selanjutnya tidak ada insentif bagi tim verifikasi, tim verifikasi dianggap menjalankan tugas rutin dan diberikan SPPD (Komando Keliling) yang besarnya tergantung jarak dan waktu sesuai aturan yang ditetapkan pemerintah.

\section{- Struktur Birokrasi}

Prosedur Operasional Standar Prosedur yang digunakan dinas pendidikan belum sepenuhnya mengacu pada Kepmendiknas Nomor 060/U/2002, pedoman teknis dan pedoman pelaksanaan. Pembagian tugas dan fungsi tim verifikasi belum ditetapkan secara jelas, kurangnya penugasan peran dan fungsi tim verifikasi di lapangan dapat mempengaruhi hasil verifikasi pelaksanaan kebijakan penyelenggaraan pendidikan dasar dan menengah unit di Kabupaten Batu Bara.

\section{SIMPULAN}

Kesimpulan dari penelitian ini adalah bahwa dilihat dari aspek komunikasi; sosialisasi pendirian sekolah di Kabupaten Batu Bara tidak dilakukan secara formal, penyampaian informasi hanya kepada panitia yang datang ke kantor untuk mengusulkan pendirian sekolah baru melalui tanya jawab. Dinas Pendidikan belum memiliki buku pegangan, kejelasan informasi tentang persyaratan pendirian sekolah dipahami dengan baik oleh para pengambil kebijakan di 
kantor. Kepala Dinas tidak bisa menolak jika ada instruksi Bupati untuk mendirikan sekolah.

Ketidakmampuannya yang

tidak konsisten sebelumnya dan sekarang. Aspek sumber daya; Pendirian beberapa sekolah menengah merupakan instruksi dari Kabupaten Aceh Selatan. Laporan tertulis atau resume hasil studi kelayakan tim verifikasi tidak ada. Pemetaan sekolah atau pemetaan sekolah tiap kabupaten juga belum ada, sarana dan prasarana sekolah yang dibangun masih kurang. Aspek disposisi; Penunjukan staf yang terlibat dalam tim verifikasi tidak diatur dengan Surat Keputusan (SK) Kepala Dinas, insentif bagi tim verifikasi studi kelayakan juga belumtersedia. Dan aspek struktur Birokrasi; Prosedur Operasional Standar (SOP) belum sepenuhnya mengarah pada Kepmendiknas Nomor 060/U/2002, pembagian kewenangan dan tanggung jawab dalam tim verifikasi tidak ada, verifikasi dilakukan secara bersama-sama.

- Komunikasi; informasi yang diberikan hanya kepada panitia pembangunan sekolah, mengenai syarat dan ketentuan pendirian sekolah baru sangat terbatas. Hal ini berimplikasi pada kurangnya informasi yang diterima masyarakat. Implikasi lain dari kurangnya sosialisasi pendirian sekolah baru adalah banyaknya sekolah yang diusulkan oleh masyarakat sehingga di daerah tertentu jumlah sekolah bertambah tetapi jumlah siswanya berkurang.

- Sumber Daya; Staf yang terlibat dalam tim verifikasi bukan SK akan berimplikasi pada staf yang merasa tidak terikat pada tim sehingga tidak ada tanggung jawab dalam pekerjaan. Syarat pendirian yang tidak terpenuhi akan berimplikasi pada lemahnya hasil studi kelayakan, sumber peserta didik yang kurang, kurangnya tenaga guru serta sarana dan prasarana yang tidak lengkap, mobil yang belum tersedia di sekolah baru berimplikasi pada terhambatnya Proses belajar mengajar di kelas, minimnya minat siswa masuk sekolah baru.

- Disposisi; tim verifikasi tidak menggunakan SK dan insentif tidak tersirat. Ini menyiratkan kurangnya komitmen dan tanggung jawab tim. Implikasi lainnya adalah kurangnya motivasi tim dalam bekerja.

- Struktur birokrasi; Kepmendiknas nomor 060 / U /2002 sebagai Standar Operasional Prosedur (SOP) belum berpedoman dengan baik, berimplikasi pada hasil studi kelayakan yang tidak sesuai. Pembagian tugas dan tanggung jawab dalam tim verifikasi yang tidak jelas akan berimplikasi pada tumpang tindih penilaian dan buruknya 
hasil keputusan yang dibuat oleh tim.

\section{DAFTAR RUJUKAN}

Amtu, Onisimus. 2011. Manajemen pendidikan di era otonomi daerah: konsep, strategi, dan implementasi. Bandung: Alfabeta. Hal 33

Baginda et al. 2020. Analysis of Smartphone Use Policy Case study in SMA Negeri Subulusalam. Proceedings of the 5th Annual International Seminar on Transformative Education and Educational Leadership (AISTEEL 2020) https://doi.org/10.2991/assehr.k.2 01124.053

Bakti, Asmara. 2017. Analisis Kebijakan Pendirian Satuan Pendidikan Dasar dan Menengah di Kabupaten Aceh Selatan. Masters thesis, UNIMED.

Edwards III George C. 2003. Implementing Public Policy. Jakarta. Hal 154

Hasibuan et al. 2019. Analysis of PDDB Online Implementation Policy (Case study at the Sunggal Branch of the North Sumatra Provincial Education Office). Proceedings of the 4th Annual International Seminar on Transformative Education and Educational Leadership (AISTEEL 2019). https://www.atlantispress.com/proceedings/aisteel$19 / 125928400$
Mayya dkk. 2019. Analisis Implementasi Kebijakan Pendidikan Inklusi Pada Sekolah Dasar. Jurnal Administrasi Pendidikan, Vol. 26 (1). https://ejournal.upi.edu/index.php /JAPSPs/article/view/19853

Sihotang DO dkk. 2020. Analisis Kebijakan Penggunaan Smartphone Di SMA Kabupaten Simalungun. Prosiding Seminar Nasional FIP 2020. https://fip.unesa.ac.id/fipppti/public/proceeding/index.php/ webinar2020/article/view/83

Sipayung. 2018. Pengaruh Gaya Kepemimpinan Kepala Sekolah Dalam Meningkatkan Kreativitas Guru Di Sma St. Maria Medan. School Education Journal PGSD FIP Unimed. Vol 8(2). https://jurnal.unimed.ac.id/2012/i ndex.php/school/article/view/982 9

Windari et al. 2018. Implementation Of School Accreditation Policy at State Elementary School In Medan Area Districts. Proceedings of the 3rd Annual International Seminar on Transformative Education and Educational Leadership (AISTEEL 2018). https://doi.org/10.2991/aisteel18.2018.187 